\title{
Agaricus bisporus production on substrates pasteurized by self-heating
}

\author{
Stephania Colmenares-Cruz ${ }^{1}$, José E. Sánchez ${ }^{2^{*}}$ (10 and Javier Valle-Mora²
}

\begin{abstract}
The aim of this work was to determine if the self-heating pasteurization procedure is technically applicable to the cultivation of Agaricus bisporus. Firstly the substrates alone (corncob, Pangola grass and a mixture of both ingredients with wood shavings) were tested. Two supplementation trials were then undertaken using soybean, wheat bran, sheep manure, sesame seed, black bean and chia. Highest production values $\left(B E=176.3 \%\right.$ and $\left.Y=26.6 \mathrm{~kg} / \mathrm{m}^{2}\right)$ were obtained using a $9 \%$ supplement, with a formula consisting of $25 \%$ each of soybean, black bean, wheat bran and chia, added at spawning and at casing. These results were comparable to those obtained with the Phase II compost traditionally used for A. bisporus cultivation.
\end{abstract}

Keywords: Portobello, Substrate preparation, Button mushroom, Mushroom cultivation

\section{Introduction}

Agaricus bisporus is the fourth mushroom species cultivated in the world, with $15 \%$ of global production $\left(34 \times 10^{6} \mathrm{t}\right.$ edible mushrooms, Royse et al. 2016). The method usually used to cultivate the white button mushroom was described by Sinden and Hauser (1950) and improved through the years by a great number of research findings (Wuest 1982). The process involves two composting phases and is used worldwide because of excellent results. Phase I is a composting treatment requiring between 6 and 14 days, according to raw materials used. Phase I helps soften straw and other raw materials, break down soluble sugars and lower the $\mathrm{C} / \mathrm{N}$ ratio. Biological (bacterial) and chemical (ammonia) activities increase during Phase I composting (Straatsma et al. 1995; Gerrits et al. 1995). This phase brings environmental challenges to growers because of odors and slurries (Mamiro et al. 2007; Beyer 2017). Phase II is a pasteurization process devoted to reduce competitor microbiota and give the substrate its biological selectivity. In Phase II, ammonia is reduced to levels that are non-toxic to $A$. bisporus (Laborde et al. 1993). Besides environmental

\footnotetext{
*Correspondence: esanchez@ecosur.mx

2 El Colegio de la Frontera Sur., Carretera al Antiguo Aeropuerto km 2.5, 30700 Tapachula, Chiapas, Mexico

Full list of author information is available at the end of the article
}

problems, the Phase II technology for producing $A$. bisporus requires time, labor and investment (Miller et al. 1990). The loss of matter during composting is also an argument for the development of mushroom cultivation alternative methods.

Agaricus bisporus is considered a litter secondary decomposer, which means that bacteria and other fungi have to break down raw materials before the mushroom can grow, however Till (1962), demonstrated that $A$. bisporus could be cultivated on a non-composted substrate, like autoclaved sawdust. Since that time, several studies about cultivation (San Antonio 1971; Sanchez and Royse 2001; Bechara et al. 2005, etc.) and also on ligninolytic activity of this mushroom (Durrant et al. 1991; Wood and Leatham 1983) have placed A. bisporus as a basidiomycete able to degrade lignin and to grow on several raw, non-composted substrates.

Several alternative methods have been developed to grow A. bisporus. They consist in preparing a noncomposted sterilized or pasteurized substrate at different temperatures, for avoiding the long composting traditional procedure (Till 1962; Mee 1978; San Antonio 1971; Sanchez and Royse 2001; Bechara et al. 2005, 2006; Coello-Castillo et al. 2009). However, none of them have been applied commercially.

A low input technology has been proposed to cultivate oyster mushrooms Pleurotus ostreatus (Villa-Cruz 
et al. 1999; Hernández et al. 2003; Barrios-Espinoza et al. 2009; Avendaño-Hernandez and Sánchez 2013). This technology is based upon the use of substrates pasteurized by self-heating. It consists on mixing raw materials with calcium hydroxide (2\%) at controlled moisture levels and depositing the substrate in a wooden crate to allow heat to warm up the entire mass for pasteurization purposes. The entire process is accomplished within two days, and has been used successfully to cultivate strains of Pleurotus species like $P$. djamor, P. citrinopileatus and $P$. eryngii, and also other edible mushroom genera including Auricularia and Agrocybe (Morales and Sánchez 2017).

The aim of this work was to determine if the self-heating pasteurization procedure is technically applicable to A. bisporus cultivation, and if production yields are comparable to those obtained using the two-phase traditional method.

\section{Materials and methods}

\section{Strains}

For spawning, the commercial variety Portobello Heirloom of Agaricus bisporus was purchased from Amycel (San Miguel de Allende, Guanajuato, México). Inocula of one or five percent were used as indicated.

\section{Substrates and supplements}

Three cultivation substrates were tested using the following agricultural byproducts obtained from local markets: (1) Pangola grass (Digitaria decumbens) cut into 2-2.5 cm lengths, (2) corncob (Zea mays) cut into $1-2 \mathrm{~cm}$ lengths, and (3) a mixture of wood shavings of the primavera tree (Tabebuia rosea) (16.6\%), with corncob (41.6\%) and Pangola grass (41.6\%). These substrates were combined with $2 \%$ hydrated lime $\mathrm{Ca}(\mathrm{OH})_{2}$ (Super Cal hidratada Grijalva), and the moisture was adjusted to $65 \%$ with tap water.

The following supplements were obtained locally: soybean (Glycine max), wheat bran, sheep manure, sesame seed (Sesamum indicum), chia (Salvia hispanica) and black bean (Phaseolus vulgaris). Supplements were ground ( $2 \mathrm{~mm}$ screen), autoclaved in high-density polyethylene bags at $1.05 \mathrm{~kg} / \mathrm{cm}^{2}\left(121{ }^{\circ} \mathrm{C}\right)$ for $20 \mathrm{~min}$ and mixed into the substrate both at spawning and prior to casing (9\% dry wt each time). Two trials of 13 and 16 treatments were conducted using single or combined supplements (Tables 1, 2).

\section{Substrate preparation}

Substrates were homogenized in a mixer MC-50 (Maquinaria Agropecuaria HML, Xalapa, Mex.), placed in a wooden crate measuring $1 \mathrm{~m}^{3}$, and then pasteurized by allowing the temperature to rise to $60-65{ }^{\circ} \mathrm{C}$. After $30 \mathrm{~h}$,
Table 1 Treatments used in the first supplementation trial (four ingredients) for the cultivation of $A$. bisporus on selfheated pasteurized Pangola grass

\begin{tabular}{lllll}
\hline Treatment & \multicolumn{4}{l}{ Supplement } \\
\cline { 2 - 5 } & Soybean & Sheep manure & Wheat bran & Sesame seed \\
\hline 1 & 0.125 & 0.125 & 0.625 & 0.125 \\
2 & 0 & 1 & 0 & 0 \\
3 & 0.333 & 0 & 0.333 & 0.333 \\
4 & 0.333 & 0.333 & 0.333 & 0 \\
5 & 0 & 0 & 0 & 1 \\
6 & 0.25 & 0.25 & 0.25 & 0.25 \\
7 & 0.125 & 0.125 & 0.125 & 0.625 \\
8 & 0.125 & 0.625 & 0.125 & 0.125 \\
9 & 0.625 & 0.125 & 0.125 & 0.125 \\
10 & 0.333 & 0.333 & 0 & 0.333 \\
11 & 1 & 0 & 0 & 0 \\
12 & 0 & 0 & 1 & 0 \\
13 & 0 & 0.333 & 0.333 & 0.333 \\
\hline
\end{tabular}

Table 2 Treatments used in the second supplementation trial (five ingredients) for the cultivation of $A$. bisporus on self-heated pasteurized Pangola grass

\begin{tabular}{llllll}
\hline Treatment & \multicolumn{2}{l}{ Supplement } & & & \\
\cline { 2 - 6 } & Soybean & $\begin{array}{l}\text { Sesame } \\
\text { seed }\end{array}$ & $\begin{array}{l}\text { Black } \\
\text { beans }\end{array}$ & $\begin{array}{l}\text { Wheat } \\
\text { bran }\end{array}$ & Chia \\
\hline 1 & 0.1 & 0.6 & 0.1 & 0.1 & 0.1 \\
2 & 0 & 1 & 0 & 0 & 0 \\
3 & 0.1 & 0.1 & 0.1 & 0.1 & 0.6 \\
4 & 0.25 & 0 & 0.25 & 0.25 & 0.25 \\
5 & 0 & 0 & 0 & 1 & 0 \\
6 & 0.25 & 0.25 & 0 & 0.25 & 0.25 \\
7 & 0.25 & 0.25 & 0.25 & 0 & 0.25 \\
8 & 0.1 & 0.1 & 0.6 & 0.1 & 0.1 \\
9 & 0.6 & 0.1 & 0.1 & 0.1 & 0.1 \\
10 & 0 & 0 & 0 & 0 & 1 \\
11 & 0 & 0.25 & 0.25 & 0.25 & 0.25 \\
12 & 1 & 0 & 0 & 0 & 0 \\
13 & 0 & 0 & 1 & 0 & 0 \\
14 & 0.2 & 0.2 & 0.2 & 0.2 & 0.2 \\
15 & 0.25 & 0.25 & 0.25 & 0.25 & 0 \\
16 & 0.1 & 0.1 & 0.1 & 0.6 & 0.1 \\
\hline
\end{tabular}

it was removed, turned and placed back in the crate. The process was completed after $45 \mathrm{~h}$ by aerating the substrate to decrease the temperature (Sánchez et al. 2016; Morales and Sánchez 2017).

Two batches (20 kg each) of full Phase II mushroom compost, designated $C_{1}$ and $C_{2}$, were obtained from two mushroom companies located near Mexico City and 
Xalapa, Veracruz. The composts were prepared using the following ingredients: wheat straw, chicken manure, canola, urea an gypsum. Full Phase II mushroom compost two $\left(\mathrm{C}_{2}\right)$ had the following composition: moisture content $69.2 \%, \mathrm{pH} 7.6$, Nitrogen $2.2 \%, \mathrm{C} / \mathrm{N}$ ratio $15-17$, and ashes $25 \%$.

\section{Cultivation}

Substrate and spawn (5\% inoculation rate, unless indicated differently) were mixed manually in $1 \mathrm{~kg}$ portions and placed in transparent polyethylene bags. To allow gas exchange, the upper end of the plastic bag was fitted into a plastic cylinder ( $4 \mathrm{~cm}$ diameter) and the hole covered with a clean white paper towel. Incubation lasted 3 weeks at $24-26^{\circ} \mathrm{C}$ and after the substrate was colonized by the mushroom mycelium, the bag was opened and a casing (peat: lime: water 1:1:3; no thermal treatment) overlay (4 cm deep) was applied. The substrate was further incubated at $18{ }^{\circ} \mathrm{C}$ and $90 \%$ relative humidity for three more weeks. Irrigation was applied daily. When used, supplements were mixed into the substrate at spawning and before applying the casing ( $9 \%$ each time). Mushrooms were harvested (three breaks) when the pileus was open and the veil broken. No attempts were made to control weed molds and diseases.

\section{Treatments}

To test the technical feasibility of $A$. bisporus cultivation on self-heated pasteurized substrates, three substrates without supplements were assayed initially. Two sets of supplementation treatments were then carried out, the first with four ingredients and 13 treatments, and the second with five ingredients and 16 treatments (Tables 1 , 2). Supplements (on a dry weight basis) were added $9 \%$ at spawning and $9 \%$ at casing. Controls were two nonsupplemented full phase composts $\left(\mathrm{C}_{1}\right.$ and $\left.\mathrm{C}_{2}\right)$ using two spawning rates of 1 and $5 \%$ for $C_{1}$, and only $5 \%$ for $C_{2}$, as indicated.

\section{Chemical analysis}

To determine Carbon/Nitrogen $(\mathrm{C} / \mathrm{N})$ ratios, reducing sugar and lipid levels, $200 \mathrm{~g}$ samples were dried in a $65^{\circ} \mathrm{C}$ oven for 5 days, ground into a fine powder and sent to the Bromatology Laboratory (Ecosur) for analysis. Carbon and nitrogen levels were determined using a Flash 2000 Analyzer (Thermo Fischer Scientific, http://www. thermoscientific.com/). Reducing sugars were measured using the 3,5 dinitrosalicylic acid (DNS) method (Miller 1959), and total lipids were determined according to Williams (1984).

\section{Evaluated parameters}

Biological efficiency (BE) values were computed using the following calculation: fresh mushroom weight divided by dry substrate weight and multiplied by 100 . The production rate (PR) was calculated by dividing $\mathrm{BE}$ by the number of days needed to obtain three flushes. Mean size of mushrooms (MMS) was calculated by dividing the weight of mushrooms by the number of mushrooms harvested per bag. Yields were estimated by dividing the production of each bag by the horizontal area exposed to mushroom production and are expressed in $\mathrm{kg} / \mathrm{m}^{2}$. The incidence of contamination was estimated visually: at the end of the spawn run, and after the first harvest, the percentage of contaminated area per each substrate bag was estimated. The result was expressed as an average.

\section{Statistical analysis}

A completely randomized design with five repetitions was used (Tables $3,4,5)$. To investigate the impact of the ingredients of the supplement mixtures on yield, a mixture design was used (Table 7). In each case, five repetitions were used and an analysis of variance and a mean separation was evaluated using Tukey's test with a significance threshold of $\mathrm{p}<0.05$. Statistical analysis was carried out using JMP version 4 (SAS 2000).

\section{Results}

\section{Cultivation on substrates without supplements}

Table 3 shows the production variables of $A$. bisporus on three substrates pasteurized by self-heating. Biological efficiency values varied between 18.5 (corncob) and 51.7\% (Pangola grass), Production Rates between 0.6 and $1.7 \%$, and yields between 2.7 and $7.6 \mathrm{~kg} / \mathrm{m}^{2}$. Statistical analysis indicated that the cultivation of the mushroom on the mixture or on Pangola grass alone gave similar

Table 3 Production variables of Agaricus bisporus cultivated on three substrates pasteurized by self-heating

\begin{tabular}{llllll}
\hline Substrate & Production (g/bag) & BE (\%) & MMS (g) & PR (\%) & Y (kg/m $\mathbf{m}^{\mathbf{2})}$ \\
\hline Mixture & $132.0 \pm 56.0^{\mathrm{a}}$ & $37.7 \pm 16.0^{\mathrm{a}}$ & $36.6 \pm 5.1^{\mathrm{a}}$ & $1.2 \pm 0.5^{\mathrm{a}}$ & $5.5 \pm 2.3^{\mathrm{a}}$ \\
Corncob & $65.0 \pm 41.1^{\mathrm{b}}$ & $18.5 \pm 11.7^{\mathrm{b}}$ & $35.0 \pm 26.1^{\mathrm{a}}$ & $0.6 \pm 0.3^{\mathrm{b}}$ & $2.7 \pm 1.7^{\mathrm{b}}$ \\
Grass & $181.2 \pm 55.7^{\mathrm{a}}$ & $51.7 \pm 15.9^{\mathrm{a}}$ & $31.25 \pm 9.7^{\mathrm{a}}$ & $1.7 \pm 0.5^{\mathrm{a}}$ & $7.6 \pm 2.3^{\mathrm{a}}$ \\
p & 0.000118 & 0.000118 & 0.9367 & 0.000118 & 0.000118 \\
\hline
\end{tabular}

Same letter in the same column indicates no statistical difference between substrates (alpha $=0.05$ )

$B E$ biological efficiency, MMS mean mushroom size (g), $P R$ production rate (\%), $Y$ yield 
Table 4 Production variables of $A$. bisporus cultivated on Pangola grass supplemented (9\%) with 13 different mixtures at spawning and casing

\begin{tabular}{|c|c|c|c|c|c|c|c|c|c|}
\hline \multirow[t]{2}{*}{ Treatment } & \multicolumn{4}{|c|}{ Supplement } & \multicolumn{5}{|c|}{ Production variables } \\
\hline & Soy bean & Sheep manure & Wheat bran & Sesame seed & $\begin{array}{l}\text { Production } \\
\text { (g/1 kg wet } \\
\text { substrate) }\end{array}$ & $\mathrm{BE}(\%)$ & MMS (g) & PR (\%) & $\mathrm{Y}\left(\mathrm{kg} / \mathrm{m}^{2}\right)$ \\
\hline$C_{1} 1 \%$ & - & - & - & - & $531.2 \pm 202.6^{\mathrm{ab}}$ & $151.7 \pm 57.9^{\mathrm{ab}}$ & $54.2 \pm 20.6^{b}$ & $5.0 \pm 1.9^{\mathrm{ab}}$ & $22.4 \pm 8.5^{\mathrm{ab}}$ \\
\hline$C_{1} 5 \%$ & - & - & - & - & $623.5 \pm 56.7^{\mathrm{a}}$ & $178.1 \pm 16.2^{\mathrm{a}}$ & $43.1 \pm 10.8^{b}$ & $5.9 \pm 0.5^{\mathrm{a}}$ & $26.3 \pm 2.3^{\mathrm{a}}$ \\
\hline 0 & - & - & - & - & $240.6 \pm 58.6^{d}$ & $68.7 \pm 16.7^{d}$ & $45.2 \pm 12.0^{b}$ & $2.2 \pm 0.5^{d}$ & $10.1 \pm 2.4^{d}$ \\
\hline 1 & 0.125 & 0.125 & 0.625 & 0.125 & $540.2 \pm 106.8^{a b}$ & $154 \pm 30^{\mathrm{ab}}$ & $50.0 \pm 12.4^{b}$ & $5.1 \pm 1.0^{\mathrm{ab}}$ & $22.7 \pm 4.5^{\mathrm{ab}}$ \\
\hline 2 & 0 & 1 & 0 & 0 & $393.2 \pm 151.8^{\mathrm{bcd}}$ & $112.3 \pm 43.3^{\mathrm{bcd}}$ & $41.4 \pm 9.8^{b}$ & $3.7 \pm 1.4^{\mathrm{bcd}}$ & $16.6 \pm 6.4^{\mathrm{bcd}}$ \\
\hline 3 & 0.333 & 0 & 0.333 & 0.333 & $497.6 \pm 47.9^{\mathrm{abc}}$ & $142.1 \pm 13.7^{\mathrm{ab}}$ & $39.8 \pm 11.1^{\mathrm{b}}$ & $4.7 \pm 0.4^{\mathrm{ab}}$ & $20.9 \pm 2.0^{\mathrm{abc}}$ \\
\hline 4 & 0.333 & 0.333 & 0.333 & 0 & $433.4 \pm 57.2^{\mathrm{abc}}$ & $123.8 \pm 16.3^{\mathrm{abc}}$ & $39.2 \pm 7.0^{b}$ & $4.1 \pm 0.5^{\mathrm{abc}}$ & $18.2 \pm 2.4^{\mathrm{abc}}$ \\
\hline 5 & 0 & 0 & 0 & 1 & $363.2 \pm 31.8^{\mathrm{bcd}}$ & $103.7 \pm 9.0^{\mathrm{bcd}}$ & $44.2 \pm 7.1^{b}$ & $3.4 \pm 0.3^{\mathrm{bcd}}$ & $15.3 \pm 1.3^{\mathrm{bcd}}$ \\
\hline 6 & 0.25 & 0.25 & 0.25 & 0.25 & $493.2 \pm 57.0^{\mathrm{abc}}$ & $140.916 .3^{\mathrm{abc}}$ & $50.0 \pm 8.7^{b}$ & $4.6 \pm 0.5^{\mathrm{ab}}$ & $20.8 \pm 2.4^{\mathrm{ab}}$ \\
\hline 7 & 0.125 & 0.125 & 0.125 & 0.625 & $401.6 \pm 30.0^{\mathrm{bcd}}$ & $114.7 \pm 8.5^{\mathrm{bcd}}$ & $42.8 \pm 11.6^{b}$ & $3.8 \pm 0.2^{b c d}$ & $16.9 \pm 1.2^{b c d}$ \\
\hline 8 & 0.125 & 0.625 & 0.125 & 0.125 & $384.4 \pm 42.3^{\mathrm{bcd}}$ & $109.8 \pm 12.1^{\mathrm{bcd}}$ & $48.0 \pm 7.6^{b}$ & $3.6 \pm 0.4^{\mathrm{bcd}}$ & $12.2 \pm 1.7^{b c d}$ \\
\hline 9 & 0.625 & 0.125 & 0.125 & 0.125 & $391.6 \pm 118^{\mathrm{bcd}}$ & $111.8 \pm 33.7^{\mathrm{bcd}}$ & $46.0 \pm 13.9^{b}$ & $3.7 \pm 1.1^{\mathrm{bcd}}$ & $16.5 \pm 1.7^{b c d}$ \\
\hline 10 & 0.333 & 0.333 & 0 & 0.333 & $394.6 \pm 89.5^{\mathrm{bcd}}$ & $112.7 \pm 25.8^{\mathrm{bcd}}$ & $35.2 \pm 11.1^{b}$ & $3.7 \pm 0.8^{b c d}$ & $16.6 \pm 3.7^{b c d}$ \\
\hline 11 & 1 & 0 & 0 & 0 & $273.2 \pm 52.6^{\mathrm{cd}}$ & $78.1 \pm 15.03^{c d}$ & $41.5 \pm 8.0^{b}$ & $2.6 \pm 0.5^{c d}$ & $11.5 \pm 2.2^{c d}$ \\
\hline 12 & 0 & 0 & 1 & 0 & $323.2 \pm 52.6^{b c d}$ & $92.1 \pm 47.5^{\mathrm{bcd}}$ & $41.0 \pm 29.34^{b}$ & $3.07 \pm 1.5^{\mathrm{bcd}}$ & $13.6 \pm 7.0^{b c d}$ \\
\hline 13 & 0 & 0.333 & 0.333 & 0.333 & $407.6 \pm 235.1^{\mathrm{abc}}$ & $116.4 \pm 67.1^{\mathrm{abc}}$ & $77.2 \pm 52.1^{\mathrm{a}}$ & $3.8 \pm 2.2^{\mathrm{abc}}$ & $17.1 \pm 9.9^{\mathrm{abc}}$ \\
\hline $\mathrm{p}$ & - & - & - & - & 0.0007 & $3.31 e-07$ & $4.524 \mathrm{e}-05$ & $3.31 \mathrm{e}-07$ & $3.31 e-07$ \\
\hline
\end{tabular}

Same letters in the same column indicate no statistical difference between treatments (alpha $=0.05$ )

$B E$ biological efficiency, MMS mean mushroom weight (g), $P R$ production rate (\%), $Y$ yield

results, and that both substrates were significantly different from corncob, whose results were lower $(\mathrm{p}=0.000)$. The weight of individual mushrooms ranged between 31.2 and 36.6 grams, and no significant difference was found between all three substrates $(\mathrm{p}=0.9367)$.

\section{Cultivation on supplemented substrate}

Table 4 shows the production variables of $A$. bisporus cultivated on Pangola grass supplemented with 13 different mixtures of soybean, sheep manure, wheat bran and sesame seed. Biological Efficiency values varied from $68.7 \%\left(\mathrm{~T}_{0}\right.$, non supplemented Pangola grass) to $178.1 \%\left(\mathrm{C}_{2}\right.$, full compost with $5 \%$ spawning rate). Statistical analysis indicated significant differences among treatments $(\mathrm{p}=0.000)$. Table 5 shows the production variables of $A$. bisporus in a second evaluation trial, cultivated on Pangola grass supplemented with 16 different mixtures of soybean, sesame seed, black bean, wheat bran and chia. Biological Efficiency values varied from $44.2 \pm 17.1\left(\mathrm{~T}_{0}\right)$ to $176.3 \pm 36.7\left(\mathrm{~T}_{4}\right.$, formulation with $25 \%$ each of four ingredients excluding sesame seed). Statistical analysis indicated significant differences among treatments, establishing four statistical groups. Group "a" with the highest BE values varying between 128.1 and $176.3 \% . \mathrm{T}_{4}$ generated a $\mathrm{BE}$ value significantly higher than that obtained with control Phase II compost
$(125.3 \% ; \mathrm{p}=0.000)$, and also produced larger mushrooms $(\mathrm{p}=0.0022)$ and higher yields $(\mathrm{p}=0.000)$ than the full compost. Yields varied between $6.5 \mathrm{~kg} / \mathrm{m}^{2}\left(\mathrm{~T}_{0}\right)$ and $26.0 \mathrm{~kg} / \mathrm{m}^{2}\left(\mathrm{~T}_{4}\right)$.

\section{Effect of supplements}

Table 6 shows the nutritional value of the substrates and supplements used in these experiments. Since the substrates used for cultivating $A$. bisporus were of low nutritional value, $\mathrm{BE}$ and yield values recorded with the substrates alone were also low. Therefore, in order to improve these production parameters, it was necessary to create better formulations through the application of supplements. In all cases, the supplemented treatments produced higher yields than the control (Pangola grass alone, $\mathrm{T}_{0}$ ) and the highest $\mathrm{BE}$ values recorded were comparable to (Table $4, \mathrm{p}=0.000$ ), or even better than (Table $5, \mathrm{p}=0.000$ ), those obtained with the full Phase II compost. A correlation analysis was performed between supplement content (nitrogen, $\mathrm{C} / \mathrm{N}$, lipids and reducing sugar) and production variables (BE, MMS, PR and yield). Correlation coefficients varied between -0.54 and 0.36 (data not shown), indicating there was no correlation between the variables tested.

Analyses of supplements using a mixture design (Table 7) indicated that the principal components of the 


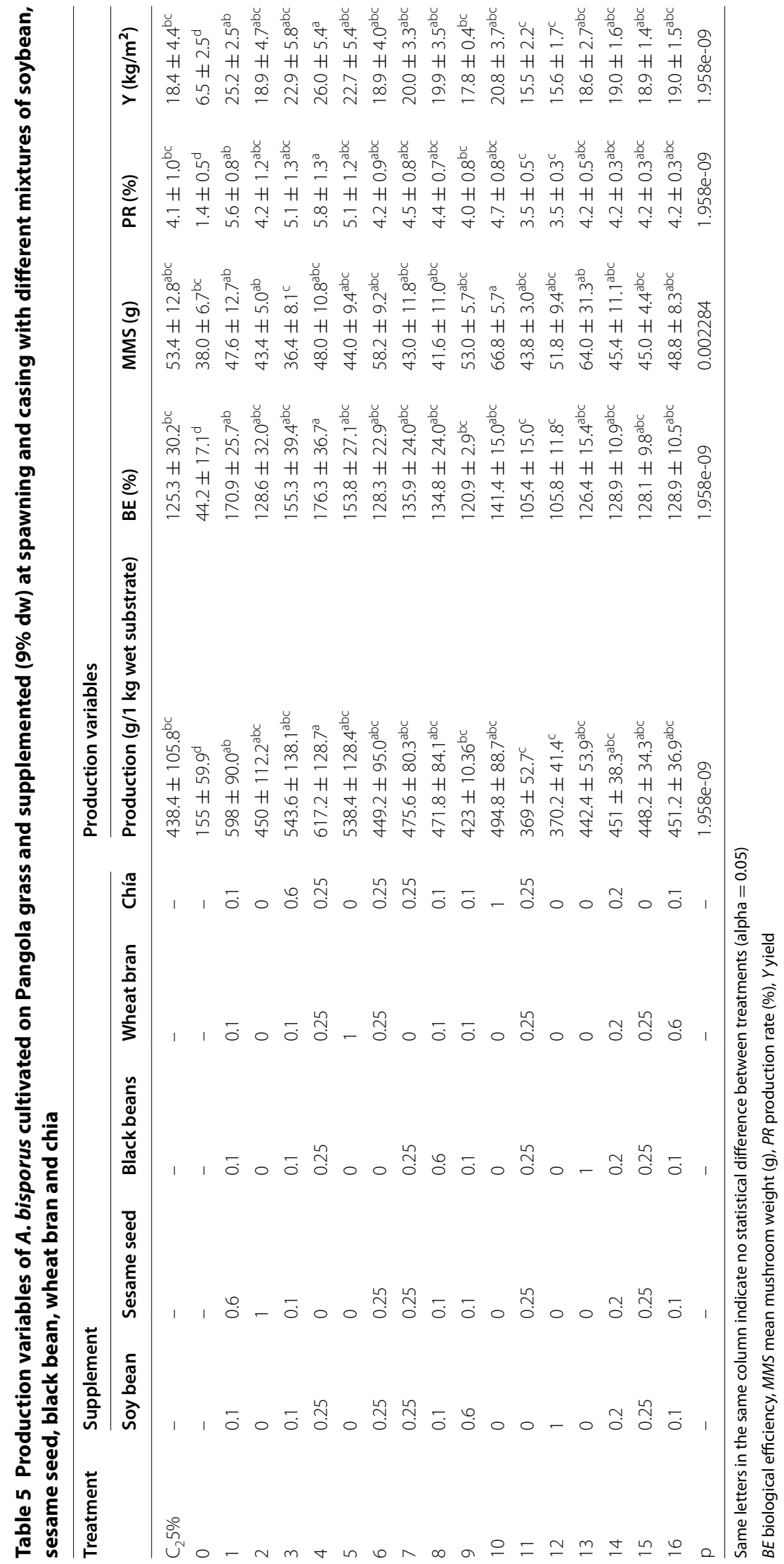


Table 6 Chemical composition of substrates and supplements used in this investigation

\begin{tabular}{llllll}
\hline Substrates & Carbon $(\mathbf{g} / \mathbf{1 0 0} \mathbf{g})$ & Nitrogen $\mathbf{( g / 1 0 0 ~} \mathbf{g})$ & $\mathbf{C} / \mathbf{N}$ & Fat $\mathbf{( g / 1 0 0 ~} \mathbf{g})$ & Reducing sugars $\mathbf{( g / 1 0 0 ~} \mathbf{g})$ \\
\hline Corncob & 51.92 & 0.42 & 123.6 & - & 34.92 \\
Grass & 49.24 & 0.82 & 60.0 & 1.3 & 17.2 \\
Mixture & 51.12 & 0.56 & 91.2 & - & 16.11 \\
Supplements & & & & & 13.7 \\
$\quad$ Sesame seed & 50.68 & 3.29 & 15.4 & 47.97 & 30.1 \\
Soybean & 42.46 & 5.61 & 7.6 & 22.52 & 15.3 \\
Sheep manure & 38.2 & 2.24 & 17.1 & 1.0512 & 66.8 \\
Wheat bran & 35.64 & 2.57 & 13.9 & 4.53 & 18.65 \\
Chia & 47.84 & 3.37 & 14.2 & 33.49 & 85.14 \\
Black beans & 35.99 & 2.95 & 12.2 & 1.65 & \\
\hline
\end{tabular}

Table 7 Parameter estimates of the mixture design of two supplementation trials evaluated

\begin{tabular}{|c|c|c|c|c|c|}
\hline Term & & Estimate & Std error & t ratio & Prob $>|t|$ \\
\hline \multicolumn{6}{|l|}{ Trial 1} \\
\hline Intercept & Zeroed & 0 & 0 & - & - \\
\hline Soybean (mixture) \& RS & & 75.828024 & 12.3874 & 6.12 & 0.0017 \\
\hline Sheep manure (mixture) \& RS & & 110.41891 & 12.3874 & 8.91 & 0.0003 \\
\hline Wheat bran (mixture) \& RS & & 97.727195 & 12.3874 & 7.89 & 0.0005 \\
\hline Sesame seed (mixture) \& RS & & 101.22084 & 12.3874 & 8.17 & 0.0004 \\
\hline Soybean (mixture)*sheep manure (mixture) & Biased & -139.0873 & 112.6716 & -1.23 & 0.2719 \\
\hline Soybean (mixture)* wheat bran (mixture) & Biased & 285.2221 & 112.6716 & 2.53 & 0.0524 \\
\hline Sheep manure (mixture)* wheat bran (mixture) & Biased & 181.01433 & 121.169 & 1.49 & 0.1954 \\
\hline Soybean (mixture)*sesame seed (mixture) & Biased & 224.53256 & 121.169 & 1.85 & 0.1231 \\
\hline Sheep manure (mixture)*sesame seed (mixture) & Zeroed & 0 & 0 & - & - \\
\hline Wheat bran (mixture)*sesame seed (mixture) & Zeroed & 0 & 0 & - & - \\
\hline \multicolumn{6}{|l|}{ Trial 2} \\
\hline Intercept & Zeroed & 0 & 0 & - & - \\
\hline Soybean (mixture) \& RS & 100.61448 & 24.08483 & 4.18 & 0.0058 & \\
\hline Sesame seed (mixture) \& RS & 140.73471 & 24.08483 & 5.84 & 0.0011 & \\
\hline Black beans (mixture) \& RS & 125.73009 & 24.08483 & 5.22 & 0.002 & \\
\hline Wheat bran (mixture) \& RS & 151.73587 & 24.08483 & 6.3 & 0.0007 & \\
\hline Chía (mixture) \& RS & 143.47691 & 24.08483 & 5.96 & 0.001 & \\
\hline Soybean (mixture)*sesame (mixture) & 63.101291 & 384.2923 & 0.16 & 0.875 & 0.891 \\
\hline Soybean (mixture)*black bean (mixture) & 344.78915 & 384.2923 & 0.9 & 0.4042 & 0.1963 \\
\hline Sesame seed (mixture)*black beans (mixture) & -242.7836 & 382.7513 & -0.63 & 0.5493 & 0.3501 \\
\hline Soybean (mixture)* wheat bran (mixture) & -183.1043 & 343.033 & -0.53 & 0.6127 & 0.8353 \\
\hline Sesame seed (mixture)* wheat bran (mixture) & Zeroed & 0 & 0 & - & - \\
\hline Black bean (mixture)*wheat bran (mixture) & Zeroed & 0 & 0 & - & - \\
\hline Soybean (mixture)*chía (mixture) & Biased & 151.41592 & 343.033 & 0.44 & 0.6744 \\
\hline Sesame seed (mixture)*chía (mixture) & Zeroed & 0 & 0 & - & - \\
\hline Black bean (mixture)* chía (mixture) & Zeroed & 0 & 0 & - & - \\
\hline Wheat bran (mixture)*chía (mixture) & Zeroed & 0 & 0 & - & - \\
\hline
\end{tabular}

substrate exerted a significant effect ( $\mathrm{p}$ values between 0.000 and 0.001 ) but there were no significant differences among the interactions between those components ( $\mathrm{p}$ values $>0.05$ ).

\section{Contamination}

Most of the spawned bags (replicates) produced mushrooms, although some exhibited poor yields due to the presence of contaminants: when the mushroom was 
cultivated on corncob, Trichoderma sp. was present in three of 20 bags spawned with A. bisporus (15\%). Also, after the second flush on corncob, the myxomycete, Didymium iridis, was detected. To our knowledge, this is the first time this myxomycete has been reported to be a contaminant of mushroom substrate. Among the 80 bags spawned for the first supplemented trial on Pangola grass (Table 4), both treatments $T_{12}$ and $T_{13}$ had one bag contaminated with the mold Trichoderma sp. by the end of the colonization period. These two bags did not produce mushrooms. One bag in each of $\mathrm{T}_{11}$ and $\mathrm{T}_{12}$ were also about $20 \%$ contaminated with the same mold by the end of the first harvest, which would explain the low mushroom production recorded with these two supplements (soybean and wheat bran alone). The general incidence of contamination by Trichoderma sp was $6.6 \%$ in Supplementation Trial 1, and the fact that contamination appeared only in some bags of the last treatments suggests it occurred during spawning. For the second Supplementation trial (Table 5), also using Pangola grass as the substrate, none of the 90 bags spawned were contaminated and all the bags produced mushrooms on a regular basis.

\section{Discussion}

The results obtained clearly demonstrate that it is possible to use the technique of pasteurization by self-heating to produce $A$. bisporus Portobello mushrooms. When the substrates were used alone, $\mathrm{BE}$ and yield values obtained were low compared to commercial data such as estimated average yields of button mushrooms in the USA $(26.9 \mathrm{~kg} /$ $\mathrm{m}^{2}$ or $6.33 \mathrm{lb} / \mathrm{sq}$ foot, NASS 2016). These low yields may be due to the low nutritive value of the substrates used (nitrogen content between 0.42 and 0.82, Table 6). However, it is noteworthy that full substrate colonization was achieved in less than three weeks, suggesting a certain selectivity for mushroom growth. The selectivity observed on the traditional full mushroom compost for the growth of A. bisporus is based on the presence of thermophilic fungi developed during phase II pasteurization (Straatsma et al. 1989, 1994; Wiegant et al. 1992). However, in the case of self-heating pasteurization, the total length of the treatment and the thermophilic phase was less than $45 \mathrm{~h}$, so the substrate was less degraded and thermophilic microorganisms had shorter time to colonize the raw substrate. The raw material was pasteurized scarcely in two days, a short time compared with the phase II composting method that requires $12-20$ days (Zied et al. 2010).

In previous investigations, researchers have shown that Phase I is not a prerequisite for Phase II (Wiegant et al. 1992; Straatsma et al. 1994; Sánchez et al. 2008; Sánchez and Royse 2009; Coello-Castillo et al. 2009). Also, by using sterile substrates, it has been demonstrated that phase II is also not necessary to grow A. bisporus (San Antonio 1971; Sanchez and Royse 2001; Bechara et al. 2005). In this work, it was found that $A$. bisporus can be cultivated in several pasteurized substrate that have not received a phase I or Phase II process. The ability to colonize and then to fructify in a self pasteurized substrate could be linked to the ligninolytic capacity of the white button mushroom (Kabel et al. 2017; ten Have et al. 2003; Bonnen et al. 1994) but also to the microbiota associated to the mycosphere (Torres-Ruiz et al. 2016). Therefore, it would be interesting to undertake further studies on this system to understand better the microbial diversity and its relationship on the development of $A$. bisporus.

Sánchez et al. (2008) used pasteurized grass $\left(6 \mathrm{~h}, 60^{\circ} \mathrm{C}\right)$ for A. bisporus production and obtained $11 \% \mathrm{BE}$ and $25 \mathrm{~g}$ mean mushroom weight. Differences may be due to strain difference, but also to a possible beneficial effect of the microbiota developed in the self-heated pasteurized substrate (Torres-Ruiz et al. 2016).

The data obtained through the supplementation trials $\left(B E=176.3 \% ; Y=26 \mathrm{~kg} / \mathrm{m}^{2}\right)$ are interesting since Schisler (1982), for example, stated that BE values between 80 and $90 \%$ are already attractive commercially. They also compare favourably with previously results $\left(\mathrm{BE}=73.1 \%\right.$ and $\left.\mathrm{Y}=12.7 \mathrm{~kg} / \mathrm{m}^{2}\right)$ obtained by cultivating brown varieties of $A$. bisporus on non-conventional, pasteurized substrates (Coello-Castillo et al. 2009; Sánchez et al. 2008). Furthermore, they exceed $\mathrm{BE}$ and yield values $\left(99.5-108.2 \%\right.$ and $25.8-28.6 \mathrm{~kg} / \mathrm{m}^{2}$, respectively) obtained by Pardo Giménez et al. (2016) who cultivated a white hybrid of $A$. bisporus on unsupplemented and supplemented (with defatted pistachio meal) Phase III compost. Sánchez and Royse (2009) using a Scytalidium thermophilum-colonized and supplemented substrate obtained BE and yield values of $99.3 \%$ and $21.19 \mathrm{~kg} / \mathrm{m}^{2}$, respectively.

With regard to supplementation, our data with soybean, a supplement used successfully on a commercial scale since first reported by Schisler and Sinden (1962), confirmed those earlier results. Sheep manure, a supplement reported to be beneficial for A. bisporus cultivation (Mee 1978; Sanchez and Royse 2001), increased yields when used at low concentrations. The manure was obtained in dry form and no information about conditions of drying were available. In order to preserve quality, the drying process may need to be carefully controlled. Sesame seed is a grain high in fat and nitrogen. This product contributed to increased mushroom production only when it was applied at low concentrations in the supplementation formula. Conversely, chia, with a similar nitrogen content to sesame seed and less fat, had a positive impact on mushroom production. Comparing 
the treatments where ingredients were applied individually, chia and wheat bran showed higher increase in $\mathrm{BE}$ than the other ingredients $(\mathrm{BE}=141.4$ and $153.8 \%$, respectively, Table 4). Specific components of each supplement with regard to amino acids, fatty acids, etc. may provide an explanation for why some mixtures promoted fruiting whereas others did not.

Supplementation is a highly complex variable where several group of formulations are recommended including proteins, lipids and carbohydrates (Wheeler and Wach 2006). It may be necessary to investigate micronutrients and individual ingredients present in the supplements in order to detect positive correlations. In this context, it has been reported that a single amino acid (isoleucine) positively stimulates mushroom yields when administered into the mushroom compost after the second flush (Royse and Sánchez 2008).

Successful colonization of the substrate by the mushroom and the low level of contamination recorded indicate that the use of raw substrates pasteurized by self-heating is a viable alternative method for cultivating Portobello mushrooms. The use of adequate supplement formulations improves mushroom development and allows the grower to obtain better yields statistically comparable to those obtained using traditional substrates (Phase II and III composts).

In regard to scaling up of the process, the self-heating pasteurization technique should be further studied (Sánchez et al. 2016). If conditions are improved, the duration of treatment may be reduced. Also, optimizing aeration would facilitate removal of the mass and reduce heat loss during turning. The technique used in this work is suitable for small growers because a crate of $1 \mathrm{~m}^{3}$ can process about $220 \mathrm{~kg}$ of grass or $380 \mathrm{~kg}$ corncobs with $65 \%$ moisture. If processing a larger amount of substrate is required, it would be possible to increase the volume of the container. However, the question rises to what extent it would be feasible, referring to the traditional technique of two phases. The larger the mass, the greater the heat generated, but also the greater the effort required to obtain a uniform temperature throughout the whole substrate, and also the greater the difficulties to moisten the substrate homogeneously.

\section{Abbreviations \\ C/N: carbon/nitrogen ratios; DNS: 3,5 dinitrosalicilic acid; BE: biological effi- ciency; PR: production rate; MMS: mean size of mushrooms; Y: yield.}

\section{Authors' contributions}

SCC assisted in the experimental design, carried out the experiments and assisted in the interpretation of the data, JES designed the experiments, supervised the execution, analyzed the results and wrote the manuscript, and JVM coordinated the statistical analysis, and critically reviewed the manuscript. All authors read and approved the final manuscript.

\section{Author details}

${ }^{1}$ Instituto de Biociencias, Blvd. Príncipe Akishino S/N, Solidaridad 2000, 30798 Tapachula, Chiapas, Mexico. ${ }^{2}$ El Colegio de la Frontera Sur., Carretera al Antiguo Aeropuerto km 2.5, 30700 Tapachula, Chiapas, Mexico.

\section{Acknowledgements}

The authors thank Dr. Gerardo Mata and Ing. Luis Aguilar, for providing the full Phase II mushroom compost samples, Lilia Moreno for her technical support, and René Andrade for identifying D. Iridis. We also thank Miguel A. LópezAnaya and Guadalupe Pérez-Escobar for their help with the chemical analyses and Dr. J.A. Buswell for critically reviewing the manuscript and correcting linguistic errors.

\section{Competing interests}

The authors declare that they have no competing interests.

\section{Availability of data and materials}

The data supporting the findings of this study are included in the main manuscript file.

\section{Ethical approval}

This article does not contain any studies with human participants or animals performed by any of the authors.

\section{Funding}

This research was supported financially by Fondos Mixtos Conacyt through the Project FOMIX-13149 "Design, construction, equipment and startup of a state center for innovation and technology transfer for the development of coffee growing in Chiapas, Mexico" and through the Project MT-11063 of Ecosur "Social and environmental innovation in coffee growing areas for reducing vulnerability".

\section{Publisher's Note}

Springer Nature remains neutral with regard to jurisdictional claims in published maps and institutional affiliations.

Received: 6 May 2017 Accepted: 19 June 2017

Published online: 24 June 2017

\section{References}

Avendaño-Hernandez RJ, Sánchez JE (2013) Self-pasteurised substrate for growing oyster mushrooms (Pleurotus spp.). Afr J Microbiol Res 7(3):220-226

Barrios-Espinoza BM, Moreno-Ruiz L, Sánchez-Vázquez JE (2009) Composteo en cajones de madera como pretratamiento del sustrato para cultivar Pleurotus ostreatus. Revista Mexicana De Micología 29:19-25

Bechara M, Heinemann P, Walker P, Romaine CP (2005) Cultivation of Agaricus bisporus on a mixture of cereal grain spawn and delayed-release nutrient supplement. Mush News 53(8):6-10

Bechara MA, Heinemann P, Walker PN, Romaine CP (2006) Non-composted grain-based substrates for mushroom production (Agaricus bisporus). Trans ASABE 49(3):819-824

Beyer DM (2017) Impact of the mushroom industry on the environment. Penn State Extension. http://extension.psu.edu/plants/vegetable-fruit/mushrooms/mushroom-substrate/impact-of-the-mushroom-industry-on-theenvironment. Accessed 27 March 2017

Bonnen AM, Anton LH, Orth AB (1994) Lignin-degrading enzymes of the commercial button mushroom Agaricus bisporus. Appl Env Microbiol 60(3):960-965

Coello-Castillo MM, Sánchez JE, Royse DJ (2009) Production of Agaricus bisporus on substrates pre-colonized by Scytalidium thermophilum and supplemented at casing with protein-rich supplements. Bioresour Technol 100:4488-4492

Durrant AJ, Wood DA, Cain RB (1991) Lignocellulose biodegradation by Agaricus bisporus during solid substrate fermentation. J Gen Microbiol 137:751-755 
Gerrits JPG, Amsing JGM, Straatsma G, Van Griensven LJLD (1995) Phase I process in tunnels for the production of Agaricus bisporus compost with special reference to the importance of water. Mush Sci 14:203-211

Hernández D, Yamasaki K, Sánchez JE (2003) A simple procedure for preparing substrate for the production of Pleurotus ostreatus. Bioresour Technol 90(2):145-150

Kabel MA, Jurak E, Mäkela MR, de Vries RP (2017) Occurrence and function of enzymes for lignocellulose degradation in commercial Agaricus bisporus cultivation. Appl Microbiol Biotechnol 101(11):4363-4369

Laborde J, Lanzi G, Francescutti B, Giordani E (1993) Indoor composting: general principles and large scale development in Italy. In: Chang ST, Buswell JA, Chiu SW (eds) Proceedings of the 1st international conference on mushroom biology and mushroom products. The Chinese University Press, Hong Kong, pp 93-113

Mamiro DP, Royse DJ, Beelman RB (2007) Yield, size and mushroom solids content of Agaricus bisporus produced on non-composted and spent mushroom compost. World J Microbiol Biotechnol 23:1289-1296

Mee HM (1978) Mushroom composting. US patent 4, 127, 964

Miller G (1959) Use of dinitrosalicylic acid reagent for determination of reducing sugar. Anal Chem 31:426-428

Miller FC, Harper ER, Macauley BJ, Gulliver A (1990) Composting based on moderately thermophilic and aerobic conditions for the production of commercial growing compost. Aust J Exp Agric 30:287-296

Morales V, Sánchez JE (2017) Self heating pasteurization of substrates for mushrooms cultivation. Int J Med Mush 19(5) (in press)

NASS (2016) Mushrooms. National Agricultural Statistics Service (NASS). Agricultural Statistics Board, United States Department of Agriculture (USDA). http://usda.mannlib.cornell.edu/usda/current/Mush/Mush-08-19-2016. pdf. Accessed 27 March 2017

Pardo-Giménez A, Catalán L, Carrasco J, Alvarez-Ortí M, Zied D, Pardo J (2016) Effect of supplementing crop substrate with defatted pistachio meal on Agaricus bisporus and Pleurotus ostreatus production. J Sci Food Agric 96:3838-3845

Royse DJ, Sánchez JE (2008) Supplementation of 2nd break mushroom compost with isoleucine, leucine, valine, phenylalanine, Fermenten ${ }^{\circledR}$ and SoyPlus ${ }^{\circledR}$. World J Microbiol Biotechnol 24:2011-2017

Royse DJ, Baars J, Tan Q (2016) Current overview of mushroom production in the world. In: Zied DC (ed) Edible and medicinal mushrooms: technology and applications. Wiley, New York

San Antonio JP (1971) A laboratory method to obtain fruit from cased grain spawn of the cultivated mushroom, Agaricus bisporus. Mycologia 63:16-21

Sanchez JE, Royse DJ (2001) Adapting substrate formulas used for shiitake for production of brown Agaricus bisporus. Bioresour Technol 77:65-69

Sánchez JE, Royse DJ (2009) Scytalidium thermophilum-colonized grain, corncobs and chopped wheat straw substrates for the production of Agaricus bisporus. Bioresour Technol 100:1670-1674

Sánchez JE, Mejía L, Royse DJ (2008) Pangola grass colonized with Scytalidium thermophilum for the production of Agaricus bisporus. Bioresour Technol 99:655-662

Sánchez JE, Moreno L, Andrade-Gallegos R (2016) Low input technology for growing mushrooms: self-heating pasteurization. WSMBMP Bulletin 15: http://wsmbmp.org/Bol15/1.html. Accessed 3 March 2017
SAS (2000) JMP 4.0, Statistical discovery software. SAS Institute. Campus Drive, Cary, NC 27513 USA. ISBN 1-58025-631-7

Schisler LC (1982) Biochemical and mycological aspects of mushroom composting. In: Penn State handbook for commercial mushroom growers Special publication. College of Agricultural Sciences, The Pennsylvania State University, State College, p 3-10

Schisler LC, Sinden J (1962) Nutrient supplementation of mushrooms compost at spawning. Mush Sci 5:150-163

Sinden JW, Hauser E (1950) The short method of composting. Mush Sci 1:52-59

Straatsma G, Gerrits JPG, Augustijn MPAM, Op den Camp HJM, Vogels GD, Van Griensven LJLD (1989) Population dynamics of Scytalidium thermophilum in mushroom compost and stimulatory effect on growth rate and yield of Agaricus bisporus. J Gen Microbiol 135:751-759

Straatsma G, Olijnsma TW, Gerrits JPG, Amsing JGM, Op den Camp JJM, Van Griensven LJLD (1994) Inoculation of Scytalidium thermophilum in button mushroom compost and its effect on yield. Appl Environ Microbiol 60:3049-3054

Straatsma G, Samson RA, Olijnsma TW, Gerrits JPG, Op den Camp HJM, Van Griensven LJLD (1995) Bioconversion of cereal straw into mushroom compost. Can J Bot 73(Suppl):1019-1024

ten Have R, Wijngaard H, Aries-Kronenburg NAE, Straatsma G, Schaap PJ (2003) Lignin degradation by Agaricus bisporus accounts for a 30 increase in bioavailable holocellulose during cultivation on compost. J Agric Food Chem 51(8):2242-2245

Till O (1962) Cultivation of mushrooms on sterile substrate and reutilization of spent compost. Mush Sci 5:127-133

Torres-Ruiz E, Sánchez JE, Guillén-Navarro GK, Ramos-Pérez DG, Royse DJ (2016) Microbial promoters of mycelial growth, fruiting and production of Pleurotus ostreatus. Sydowia 68:151-161

Villa-Cruz V, Huerta G, Sánchez JE (1999) Solid fermentation of a corn cobcoffee pulp mixture for the cultivation of Pleurotus ostreatus. Micol Neotrop Apl 12:67-74

Wheeler D, Wach MP (2006) Re-evaluating supplementation. Mushroom News 54:4-11

Wiegant WM, Wery J, Buitenhuis ET, De Bont JAM (1992) Growth promoting effect of thermophilic fungi on the edible mushroom Agaricus bisporus. Appl Environ Microbiol 58:2654-2659

Williams S (ed) (1984) Crude fat or ether extract. Official methods of analysis of the Association of Analytical Chemists. AOAC, Arlington, p 259

Wood DA, Leatham GF (1983) Lignocellulose degradation during the life cycle of Agaricus bisporus. FEMS Microbiol Lett 20:421-424

Wuest PJ (1982) Pasteurization during the mushroom grow cycle Penn State handbook for commercial mushroom growers. The Pennsylvania State University, Pennsylvania, pp 89-91

Zied DC, Almeida-Minhoni MT, Pardo González JE, Pardo Gimenez A (2010) A study of compost added to a casing technique in Agaricus bisporus cultivation from phase III bulk compost. HortScience 45(11):1649-1653

\section{Submit your manuscript to a SpringerOpen ${ }^{\circ}$ journal and benefit from:}

- Convenient online submission

- Rigorous peer review

- Open access: articles freely available online

- High visibility within the field

Retaining the copyright to your article

Submit your next manuscript at springeropen.com 